\title{
On the macroeconomics of universalistic social policy and economic and social rights
}

\author{
Andrew Martin Fischer \\ Institute of Social Studies (The Hague), Erasmus University Rotterdam, The Netherlands
}

The UN Women (2015) flagship report, Progress of the World's Women 2015-2016: Transforming economies, realizing rights (hereafter Progress), is an important contribution to global social policy making. Chapters 2 (on employment) and 3 (on social policy) are particularly inspired. More generally, the overarching emphasis that economic and social rights need to be conjoined with universalistic approaches to social policy is an especially important message. Progress stakes this position at the outset by asserting that a 'comprehensive approach to social policy that combines universal access to social services with social protection through contributory and non-contributory transfer systems is the best way to realize economic and social rights for all without discrimination' (p. 15; also see chapter 3, p. 132). This emphasis is crucial because, otherwise, the human rights based approach advocated by the report is sufficiently generic to be unhelpful for substantive policy-making.

To clarify this point, human rights based approaches are arguably founded on universalistic principles of social provisioning and social security, as stipulated by Langford (2009), and many advocates of rights-based approaches implicitly (and sometimes explicitly) evoke a universalistic approach to social policy through their discourse of rights (as does Progress). However, in the quest to operationalize these approaches, a degree of ambiguity often enters into the translation from ethics to practice. For instance, does the principle of non-discrimination imply universalism (i.e. the same treatment for all) or targeting? As pointed out by Mkandawire (2005: 5), post-modern and/or feminist scholars have criticized universalism along these lines, in that purportedly universalistic policies have often reflected fundamental underlying societal biases, such as racial or gender biases. In turn, this implies that a degree of selectivity is required in order to allow for the practice of positive discrimination. ${ }^{1}$ Similarly, the principle that programmes should focus on marginalized, disadvantaged and excluded groups can be easily construed as a rationale for targeting, particularly when asserted in the absence of any substantive discussion of policy. The emphasis on reducing disparity does not, in itself, resolve debates between targeting and universalism given that proponents of targeting have posed it as more equalizing than universalism. The principle that people should be recognized as key actors in their own development, rather than as passive 
recipients of commodities and services, could sit quite comfortably with the logic of right-wing political attacks against universalism, which frame welfare as dis-incentivizing people from taking responsibility for themselves. It could also be attributed as a rationale for using conditionalities in cash transfers, for labour market activation policies, or for other behaviourally inspired approaches of disciplining welfare recipients. The ethical principles offered by human rights based approaches do not necessarily provide a clear path through these very politicized options.

Indeed, many advocates of human rights based approaches for development appear to acquiesce to targeting as the de facto status quo, albeit this partly reflects a degree of conceptual slippage, referring to the use of targets in development goals rather than targeting in social policy. ${ }^{2}$ Although the potential fragmentation of citizenship rights that the latter can entail should be a major bone of contention for human rights advocates, it rarely figures in their analyses, albeit with some exceptions. ${ }^{3}$ While the avoidance of these contentious issues - perhaps by oversight - provides the appearance of politically neutral moral authority in an otherwise thorny field of politicized policy-making and ideological disputes, it also misses a valuable opportunity to explicitly re-embed human rights into their earlier post-war association with welfare states and Keynesian commitments to full employment. Instead, human rights approaches risk being subverted as monitoring and disciplinary devices for policy agendas that are otherwise quite antithetical to the spirit of universal rights. It is in this sense that this edition of Progress makes a vital contribution in clarifying the mutually reinforcing interdependence between human rights and universalistic social policy, thereby adding to the momentum within the UN towards a consensus around this understanding.

However, in a similar respect, some of the more problematic parts of the Report concern chapter 4 on macroeconomic policy. One important omission is the option of corporate taxation as a means to expand the tax base. More broadly, the chapter does not provide a convincing answer to the fundamental question of whether a human rights framework can actually provide guidance through the extremely politicized and ideological field of macroeconomic policy-making and its relation with social policy, or at least not without some grounding in substantive policy positions.

On the first point, Progress is conspicuously silent on corporate taxation as an option to maximize the resources for substantive equality through mobilizing tax revenues, whether by improving efficiency and or widening the tax base (pp. 211215). It briefly mentions the dilemma of transfer pricing later in the section under global economic governance, acknowledging that this does undermine the maximum available resources principle of human rights based approaches (see p. 225 and then the recommendation on p. 228). This acknowledgement of tax avoidance appears to implicitly support the Southern-led proposal to establish an intergovernmental body within the UN on international cooperation in tax matters in the Third International Conference on Financing for Development in Addis Ababa in July 2015 (which was blocked by Northern countries at the conference). However, in this light, it is doubly strange why corporate taxation is not mentioned as an option for expanding the tax base. As noted by Montes (2015) in a blog following the Addis conference, developing countries derive a greater proportion of their tax revenue from corporate taxes than developed countries (as much as $50 \%$ in some cases), and 
the negative effects of corporate tax avoidance and evasion are twice as large in non-OECD (Organisation for Economic Co-operation and Development) as in OECD countries. Montes contends that the limitations of developing countries to collect corporate taxes have translated into higher tax burdens on purely domestic enterprises, including on smallholder farmers and small businesses in which women disproportionately participate. He also highlights the irony that the lost revenues obstruct the ability of states to apply the 'maximum available resources' to fulfil their human rights obligations, even though many Northern states entered the Financing for Development conference stressing the importance of gender equality and human rights, while also blocking the developing countries in their attempts to address corporate tax avoidance. Notably, subsequent OECD proposals published in October 2015 as part of its two-year Base Erosion and Profit Shifting (BEPS) project have also done little to address these Southern concerns. Despite addressing this efficiency side of the corporate taxation question via the issue of tax avoidance and evasion, Progress nonetheless fails to connect these concerns with the more general story about lowering norms for corporate taxation since the 1970s.

On the second point, part of the reason why the chapter is somewhat unconvincing is because of a degree of conceptual fuzziness. It clarifies macroeconomic policy as monetary and fiscal policy, but then characterizes both as typically focusing on a narrow set of goals, such as increasing economic growth rates or reducing price inflation to extremely low levels. As such, it argues that these policies are often considered to be gender-neutral because they deal with aggregates that typically do not have any reference to gender equality, even though they have far-reaching gender implications (e.g. see p. 195). Progress then elaborates on three areas where macroeconomic policies currently constrain progress towards substantive equality: narrow goals and gender biases; insufficient focus on employment creation; and insufficient resources to sustainably finance the social policies required to ensure gender equality and positive distributional consequences (see pp. 197-198).

These two realms of macroeconomic policy need to be differentiated. The characterization of narrow goals applies to the case of monetary policy, although it should be noted that 'maximum' employment is one of the three statutory objectives for monetary policy in the US Federal Reserve Act (the US Federal Reserve presumably being a model of independent central banking). ${ }^{4}$ In this respect, the way that full or maximum employment is conceived has been more a matter of ideology than of goals. The same applies to the theoretical blind spots concerning the institutional conditions that allow the fullness of employment to influence wages and inflation, such as the bargaining power of labour. Notably, the weakening of labour bargaining power explains much of the stagnation of wages in most OECD countries since the 1970s. Indeed, recent International Monetary Fund (IMF) research by Jaumotte and Osorio Buitron (2015) has also recognized the relation between labour bargaining power and inequality, as measured by the decline in the share of workers affiliated with trade unions and the fall in the minimum wage relative to the median income, both of which are significantly associated with rising inequality. One hopes that central bankers of the world unite in reconsidering, based on these and other findings, the classical assumptions 
about labour demand and wages that underlie their assessments of 'natural' rates of unemployment.

However, the characterization of fiscal policy as sharing similarly narrow goals as monetary policy appears to be a conflation of these two policy realms. Fiscal policy in the aggregate is an important variable of economic activity and its constraints are also generally conceived in the aggregate. However, unlike monetary policy, fiscal policy necessarily deals with a wide range of policy realms, as a function of the financing of various government ministries by the finance ministry (or treasury). Social policy has always played a prominent role in fiscal policy if only because it constitutes among the largest categories of government expenditure, in rich as well as in poor countries. For example, government expenditure on education is particularly large in most countries. It has also long been understood that the redistributive potential of fiscal expenditures depends on how these expenditures are used, particularly in social policy, and, inversely, that the redistributive potential of social policy needs to be conceived relative to the broader fiscal context of taxation and spending. 5

While the challenge with monetary policy is to make implicit politics explicit, it is precisely the overtly political character of fiscal policy and its deep immersion into the intimate spheres of social politics that renders it so prone to ideological contestation. If fiscal policy proves to be gender-biased, it is probably more a matter of the gender biases that pervade such politics, rather than a lack of references to gender equality in aggregate fiscal goals as such. The challenge of a human rights framework is to provide guidance through these politics, particularly in settings where changes to existing fiscal and social policy systems involve deeply embedded power relations and vested interests employing seductive ideologies about the best ways to address the generic concerns raised by a human rights framework. This is particularly vital when certain ideological positions have been closely associated with devastating consequences for development and, by consequence, for human rights.

A good example is provided by the recent mainstream revival of concerns about inequality. As argued in Fischer (2012), simply naming the problem of inequality does not solve the intractable policy debates about how to deal with it. For instance, in the midst of the UN-led consultation on inequalities in 2012 and well before the frenzy surrounding Piketty (2014), The Economist (2012) acknowledged the potential dangers of inequality. However, it placed the brunt of the blame on state-owned enterprises and monopolies in China, oligarchs in Russia and India, market-obstructing labour unions everywhere, and 'misdirected welfare spending' in rich countries. The last point refers to social spending on the non-poor, although the editors appear to conflate (or commit a rhetorical sleight of hand) between social assistance and more general social spending, such that we are led to presume that general public provisioning in education and healthcare amounts to welfare spending. This 'biggest target for reform' should be addressed through raising retirement ages, means-testing public spending, and using some of the saved cash for education in a market-reformed and union-free school system. This is combined with the usual policy advocacy for further liberalizations and market reforms related to competition and transparency (particularly with respect to emerging economies). As such, the editors provide a diagnosis 
and cure for inequality that perpetuates the neoliberal condemnation of government policy and planning as the principal source of problems, and of inequality as emerging from market distortions, even though the policy agendas associated with this perspective have arguably been at the heart of rising inequalities since the 1970s in the first place.

Similar narratives have abounded in the mainstream literature with varying hues of nuance. The Economist simply provides - as it usually does on most current issues - one particularly seductive narrative for relatively easy erudite public consumption. Nonetheless, similar ideational undertones pervade relatively more moderate positions. For instance, the recent World Development Report 2013: Jobs (World Bank, 2012: p. 257) similarly advises labour market deregulation and targeted social protection among a range of other liberalizations and amidst a setting of macroeconomic stability. Gender concerns enter occasionally, such as under the proposals for targeting the investment climate, which should tackle market imperfections or government failures that prevent women's labour force participation. It is clear that these policy positions have not fallen far from the neoliberal tree, insofar as inequalities, discrimination and disadvantage are conceived in terms of market obstructions.

The predicament for human rights approaches is that the advocates of these policy paradigms claim to address the concerns raised by human rights. Indeed, Hayek and his progenies have long argued that there is a harmony between the economic freedoms promoted by neoliberalism and the civil and political freedoms classically championed by human rights; the contemporary expression of this position is perhaps best represented by Easterly (2013). Hence, in the absence of policy specifications beyond generic principles, many come to fill the void, more or less reproducing the spectrum of political and ideological policy positions. While it might be argued that the attractiveness of human rights is that they transcend these messy ideological policy disputes by imposing ethical standards to which all policy paradigms must conform, in effect they do not resolve these disputes. Rather, the de-politicization that is usually entailed in the process of generating a consensus on generic principles - or goals, such as with the Millennium Development Goals (MDGs) and Sustainable Development Goals (SDGs) - runs the risk of giving an upper hand to the more dominant orthodox positions within the spectrum of these debates, particularly given the emphasis of targeting within these principles. $^{6}$

Even in situations where there is a motivation to move social policy in more universalistic directions, and where there are resources to fund this, social policy reforms are usually entangled with the parallel politics of fiscal reform. A good example is in China, where the necessity of social policy reform has been recognized by the government since the 1990s given the sharp segregation of rural and urban residents, particularly in a context of rapid urbanization where such designations have long become antiquated. A major challenge of such reform, however, is tied up with reforming the regional fiscal system given that most of the spending responsibilities related to social policy are assigned to sub-central levels of government (e.g. provinces and below), even though it is generally agreed that their share of tax revenues, combined with centrally coordinated transfer payments, have been insufficient to cover these assigned responsibilities. ${ }^{7}$ The insufficiency has impelled these lower levels of government to 
rely on various forms of non-tax revenue generation, such as land transfer fees and other administrative fees, even though these have been regressive forms of revenue mobilization and have been quite controversial in human rights terms given their reliance on land appropriation. ${ }^{8}$ Borrowing restrictions on sub-central levels of government have also been partly circumscribed by the practice of using local state-owned investment vehicles to borrow from local state-controlled financial institutions, particularly following the global financial crisis of 2007-2009, although this has reinforced the reliance on land appropriation as a model for both local development and local government financing. The central government has been attempting to address these issues through fiscal reform, which is understood as vital for reforming and expanding the social security and health insurance systems. ${ }^{9}$ Nonetheless, the increasing fiscal imbalances highlight the increasingly crucial role of centrally coordinated transfer payments in balancing the regional fiscal system, particularly since 2007, and also in advancing social policy reforms. The politics of this has also been very sensitive given that the increasing reliance on regional subsidies has come under criticism, particularly in coastal surplus provinces, due to the perception that it encourages dependence, particularly in ethnic minority western provinces. ${ }^{10}$

More specifically with respect to health care in China, different views and vested interests compete on the question of how to reform, each with different fiscal implications. For instance, Lin (2012: 430) analyses how, in the policy debates leading up to the comprehensive health system reforms in China in 2009, different fiscal options were lobbied by different ministries: the Ministry of Finance favoured demand-side financing such as health insurance, with an idea of the need for consumer choice; the Ministry of Labour and Social Security favoured a single social protection system under its management; and the Ministry of Civil Affairs preferred the Medical Assistance scheme as a cash benefit. Even though it was weaker within this ministerial hierarchy, the Ministry of Health was left to argue for supply-side controls over health costs through budget subsidies to providers (and thereby curtailing the practice of public hospitals and providers effectively operating as private providers), as essential for dealing with issues of equity and access (Lin, 2012: 430). The close connection to fiscal policy again needs highlighting: as argued by Lin, a particularly important structural factor derailing reforms in the 1990s and 2000s was, as discussed above, the decentralized public administration and paucity of intergovernmental financial transfers since the economic reforms of the 1980s, which gave little clout to the central government over provincial and municipal governments, hospitals and doctors, in contrast to pharmaceutical companies that exerted power at all levels (Lin, 2012: 431). In other words, progressive reforms in the health system in China have been predicated on the reinvigoration of substantial regional fiscal redistribution and a strong central government role in coordinating this redistribution.

Progress does actually address many of these points in chapter 3 on social policy, such as the importance of supply-side factors in social provisioning and in cautioning against a single-minded obsession with demand-side cash transfers. However, the strength of that chapter, in creating strong links between human rights and substantive social policy positions, does not carry over as effectively into chapter 4 , where the policy recommendations are overly generic. The challenge with the human rights framework 
provided remains how to derive substantive guidance through complex and politicized fiscal policy processes, without specifying more precisely the fiscal policy modalities that are best aligned with supporting a universalistic social policy agenda. For the developing countries, this would include an activist use of fiscal policy, not simply for demand management but also for funding the deep structural transformations required for development, in the absence of which the gender implications are generally quite dire. However, perhaps this was intentionally left for the reader to divine from the otherwise very rich text, precisely because of the politics of pushing too far against orthodoxy within the UN itself.

\section{Notes}

1. In response to these criticisms, Mkandawire (2005: 5-6) notes that the most gender-progressive policies are found in societies where universalism is also an integral part of social policies. He also advocates targeting within universalism (re. Skocpol, 1991) as a means to adapt to difference and diversity. It should be noted that there is a huge difference between targeting within a universalistic system versus targeting within a residualist system. For further discussion, see Fischer (2012).

2. For instance, Langford (2010) refers to targeting in the sense of MDG targets.

3. Exceptions include Langford (2009), who considers some of these dimensions in his engagement with notions of trade-offs as typically presented in welfare (i.e. neoclassical) economics. However, this dimension of social policy is entirely absent from the review of various criticisms of rights-based approaches by Gready (2008).

4. For example, see http://www.federalreserve.gov/faqs/money_12848.htm

5. For instance, see Korpi and Palme (1998), Rothstein (2001), and Mkandawire (2005).

6. See Fischer $(2010,2013)$ for a further elaboration of this argument, also with respect to the MDGs and the exclusive focus on absolute money-metric poverty measures, which carry similar biases.

7. For example, see Brys et al. (2013).

8. On this last point, also see Wong $(2010,2013)$ and Shen et al. (2012).

9. See a discussion of this in Wong $(2010,2013)$.

10. For further discussion, see Fischer (2015).

\section{References}

Brys B, Matthews S, Herd R, et al. (2013) Tax Policy and Tax Reform in the People's Republic of China (OECD Taxation working papers no.18). Paris: Organisation for Economic Co-operation and Development (OECD).

Easterly W (2013) The Tyranny of Experts: Economists, Dictators, and the Forgotten Rights of the Poor. New York: Basic Books.

Fischer AM (2010) Towards genuine universalism within contemporary development policy. IDS Bulletin 41(1): 36-44.

Fischer AM (2012) Inequality and the universalistic principle in the post-2015 development agenda. Official Background Paper prepared for the global thematic consultation on addressing inequalities in the post-2015 development agenda, UNICEF and UN Women, November 2012. Available at: https://www.worldwewant2015.org/node/285766

Fischer AM (2013) The political within the depoliticised: Poverty measurement and implicit agendas in the MDGs. In: Langford M, Sumner A and Yamin AE (eds) The MDGs and Human Rights: Past, Present and Future, Chapter 5. Cambridge: Cambridge University Press, pp. 119-142. 
Fischer AM (2015) Subsidising Tibet: An interprovincial comparison of western China up to the end of the Hu-Wen administration. China Quarterly 221: 73-99.

Gready P (2008) Rights-based approaches to development: What is the value-added?. Development in Practice 18(6): 735-747.

Jaumotte F and Buitron CO (2015) Inequality and labour market institutions. IMF Staff discussion note SDN/14/15, July 2015. Washington, DC: International Monetary Fund.

Korpi W and Palme J (1998) The paradox of redistribution and strategies of equality: Welfare state institutions, inequality, and poverty in the Western countries. American Sociological Review 63(5): 661-687.

Langford M (2009) Social security and children: Testing the boundaries of human rights and economics. In: Marks S, Andrassen B and Sengupta A (eds) Freedom from Poverty as a Human Right: Economic Perspectives. Paris: UNESCO Publishing, 2009, pp. 193-217.

Langford M (2010) A poverty of rights: Six ways to fix the MDGs. IDS Bulletin 41(1): 83-91.

Lin V (2012) Transformations in the healthcare system in China. Current Sociology 60(4): 427-440.

Mkandawire $\mathrm{T}$ (2005) Targeting and universalism in poverty reduction (Social Policy and Development Programme paper. no. 23). United Nations Research Institute for Social Development, Geneva, December.

Montes M (2015) An Orphaned Tax Agenda? Sacrificing Good Governance and Tax Justice in the Addis Ababa Outcome (UNRISD Think Piece series, 18 August 2015). Geneva: United Nations Research Institute for Social Development.

Piketty T (2014) Capital in the Twenty-First Century. London: Belknap Press.

Rothstein B (2001) The universal welfare state as a social dilemma. Rationality and Society 13(2): 213-233.

Shen C, Jin J and Zou H-f (2012) Fiscal decentralization in China: History, impact, challenges and next steps. Annals of Economics and Finance 13(1): 1-51.

Skocpol T (1991) Targeting within universalism: Politically viable policies to combat poverty in the United States. In: Jencks C and Peterson PE (eds) The Urban Underclass. Washington, DC: The Brookings Institution, pp. 411-436.

The Economist (2012) True progressivism. The Economist, 13 October 2012. Available at: http:// www.economist.com/node/21564556

UN Women (2015) Progress of the World's Women 2015-2016: Transforming economies, realizing rights. New York: UN Women.

Wong CP (2010) Fiscal reform: Paying for the harmonious society. China Economic Quarterly 14(2): 20-25.

Wong CP (2013) Reforming China's public finances for long-term growth. In: Garnaut R, Fang C and Song L (eds) China: A New Model for Growth and Development. Canberra, ACT, Australia: ANU E Press, pp. 199-219.

World Bank (2012) World Development Report 2013: Jobs. Washington, DC: World Bank. 